\title{
We Live Surrounded by Pigs: Naming the Space
}

\author{
Dan Ungureanu (Prague)
}

\begin{abstract}
The geographical nickname is a complex entity, both geographic, social and linguistic. The study is a sociolinguistic one. It focuses on the relation between language and space in Italy, Germany, Switzerland and Romania. We present the widespread practice of giving collective nicknames to the inhabitants of neighbouring villages or cities. This nicknaming reinforces the collective local identity, and defines narrowly the acceptable social and linguistic space. The individual and collective identity of the speakers is constructed through these nicknames. The local nicknames disappear in the 1950-1960, and are gradually replaced by other nicknames, encompassing larger geographical areas. These new nicknames reflect the new migrations.
\end{abstract}

\section{$1 \quad$ Introduction}

The article first defines narrowly the nickname, in contrast to normal names. We will underline the essential differences. From here, we narrow our focus on geographical nicknames. We then illustrate this widespread custom in different Western countries and further.

Then we show the shift between old village nicknames (who are fast disappearing) to new regional nicknames, in Romania.

There are some differences between name and nickname, both symbolic and functional:

\begin{tabular}{|l|l|l|l|}
\hline & & name & nickname \\
\hline 1 & social structure & Society (Gesellschaft) & Community (Gemeinschaft) \\
\hline 2 & when given & at birth & $\begin{array}{l}\text { entrance in the adult life, after } \\
\text { some significant event; or a signifi- } \\
\text { cant characteristic of the person }\end{array}$ \\
\hline 3 & durability & permanent & may change \\
\hline 4 & validity & valid erga omnes & $\begin{array}{l}\text { used only by friends or } \\
\text { used only by family or } \\
\text { used only by spouse }\end{array}$ \\
\hline 5 & acceptance & $\begin{array}{l}\text { accepted by self, family } \\
\text { and state }\end{array}$ & $\begin{array}{l}\text { not accepted by self (in many cas- } \\
\text { es) }\end{array}$ \\
\hline
\end{tabular}




\begin{tabular}{|l|l|l|l|}
\hline 6 & semantics & $\begin{array}{l}\text { no meaning, } \\
\text { or laudatory, } \\
\text { or related to a celebrity }\end{array}$ & $\begin{array}{l}\text { describing a characteristic, } \\
\text { or insulting, } \\
\text { or describing an event }\end{array}$ \\
\hline 7 & $\begin{array}{l}\text { structure of the } \\
\text { group }\end{array}$ & hierarchy & equality \\
\hline 8 & connotations & social class or none & familiarity \\
\hline
\end{tabular}

Table 1: Names and nicknames

When the Romanian poet Marin Sorescu observes Duminica oamenii $n$-au porecle ${ }^{1}$ - 'on Sundays, people have no nicknames' he means that, on Sundays, the implicit irony, conflict and contempt existing in the nicknames stop, and there is a taboo during the day of divinely imposed harmony - a day when nobody may be made fun of.

Another taboo, less visible, covers the endearment nicknames given by husband to wife and reciprocally: nobody else may use them, and they express a form of symbolic possession.

Nicknames are not used erga omnes: they are used within a narrow, closed circle of friends, and their use symbolises equality.

\section{Geographical nicknames}

\subsection{Geographical nicknames in Italy}

The medieval history of Italy is a history of small wars between cities and of civil wars between political factions within cities. The level of trust rarely went beyond the nuclear family, the enlarged family, the clan, and never beyond the level of the village or the city. The campanilismo, or parochialism, is reflected in the nicknames.

In Engiadina (cf. Romansh - Rumantsch 2013),

- the inhabitants of Sent are called asens, 'donkeys';

- the ones from Scuol are called porcs, chucals, 'pigs'.

In Piemont, in Valsesia, (cf. Molino 2012).

- the inhabitants of Campertogno are called ravicci, 'radishes';

- Piode - muciaréi, 'crazy or whimsical';

- Rassa - treméndi, 'the frightful ones';

- Mollia - brüšóign, 'the burned ones'

In Switzerland, Canton Ticino, Capriasca:

- Cagiallo - barín, 'the rams';

- Bidogno - lapín, 'the gossips';

- Corticiasca - bécch, 'the bucks';

- Roveredo - cavréd, 'the kids;

- Lopagno - giüdée, 'the Jews or the traitors';

- Sala - müi, muli, 'the donkeys'.

\footnotetext{
${ }^{1}$ Cf. Sorescu's narrative poems from the six volumes La lilieci (1973-1980): Volum I. La lilieci. Duminica oamenii n-au porecle.
} 
- Airolo - coruf, böi, 'ravens, oxen';

- Quinto - baiàf, 'liars'.

In Lombardia, Monza and Brianza (cf. MBNews 2015),

- Passirana - mangiagatti, 'cat-eaters';

- Cogliate - buscitt, 'the calves';

- Vimercate - gratagainn, 'the hen-thieves';

- Lazzate: - i boeu, 'the oxen';

- Mariano Comense - $i$ giudee, 'the Jews', 'the traitors';

- Ceriano Laghetto - $i$ anadin, 'the ducks';

- Barlassina - i asnitt, 'the donkeys';

- Trezzo - $i$ mangiaghèzz, 'the lizard-eaters';

- Brembi - $i$ gialdon, 'the yellow ones' (because of the pellagra);

- Melz - $i$ oregiatt, 'the long-eared ones'.

In Lombardia, Cremasco:

- Bagnolo - Ladr, 'the thieves';

- Romanengo - Gacc, 'the cats';

- Rovereto - Pesa azit; 'the ones who pee vinegar'.

In Lombardia, Bergamo (cf. Universicà s. a.):

- Caravaggio - $i$ purceli, 'the piglets';

- Cornalba - i asegn, 'the donkeys';

- Dorga - i sorech, 'the mice';

- Monte di Nesse - i gnorancc, 'the ignorants';

- Dissimo - piöcc, 'the lice';

- Sagrogno - salvédi, 'the wild ones'.

In Brescia (cf. Universicà s. a.):

- Brescia - maia-sorghe, 'rat-eaters';

- Castelletto - maledecc, 'the cursed ones';

- $\quad$ Fiesse - martorei, 'the martens' (hen-thieves);

- San Gervasio: - porchi 'the pigs';

- Verolavecchia - bo, 'the oxen'.

In Salento:

- Giurdignano - tignusi, 'the mangy ones';

- Carpignano - giudei, 'the Jews' or 'the traitors';

- Muro Leccese - porchi, 'the pigs'.

In Sardinia:

- Orgosolo - butzaios, 'thieves';

- Oliano - muzzurros, 'the ones with the cut ears' (punishment for stealing sheep);

- Sassari - magna-caule, 'the cabbage eaters';

- Oruno and Bitti (reciprocally) - zullos, 'idiots';

- Onani-rospes, 'the brutes'. 
There is a strong asymmetry in the Italian culture: when Italians leave Italy, they keep a strong feeling of community and do not assimilate. When other people immigrate in Italy, they are easily absorbed in the local community.

These nicknames reflect the strong sense of local collective identity and the high mistrust in strangers.

\subsection{Geographical nicknames in France}

One has many data for France. We will quote from this abundance the ones from Dauphiné, a mountainous, poor area in the Alps (cf. de Batines 1840: 62).

- Renouillard de Moirans, pêchou de Noyarey; ${ }^{2}$

- Gloriau de Saint-Quentin, 'braggarts from Saint-Quentin', reneyou de Veurey, 'renegades from Veynet';

- Ventaret de Seyssin, moquou de Sassenageo, 'mockers from Sassenage';

- Cocoâre de Revel, opiniatro d'Uriageo, 'pigheaded from Uriage';

- Berlaude de Voreppe, orgueillou de Bernin, 'self-importants from Bernin';

- $\quad$ Sangsuë de Bivier, 'leeches from Bivier', morgan de Fontanin;

- Chassou de Saint-Imier, boutacié de-ver Crolle;

- Malavisa d'Eybens, 'clueless from Eybens', fagotié d'Echirolle,

- Fromagie de Chatrousse et du Villard-de-Lan,

- Canaille du Sapey, 'rabble from Sapey', chicanou de Meylan, 'quarrelsomes from Meylan' [...]

The list continues for two pages, unforgiving and not forgetting. There is no love lost between the author and every single village from the Dauphiné.

The personal name is the degré zéro of the name: ideally, it refers to a single person. The geographical nickname is the degré zéro of the dialect: it is understood in only two, three, maximum ten villages. The geographical nicknames, being the most dialectal words that exists, are also the most vulnerable. The roads and television that became general after 1945 increased the circulation of people and ideas, better institutions and governance increased the trust: these village nicknames disappeared very soon, many of them even before being recorded. The French historian Fernand Braudel observes that in the Middle Ages and up to the end of the Ancien Régime, people married in a narrow circle of no more than twenty kilometres around their village. In the $\mathrm{XX}^{\text {th }}$ century, the collective identity went from local to national to continental and beyond. As countries urbanized, the Gemeinschaft was elbowed out by the Gesellschaft.

\subsection{The opposite direction: from the nickname to the name}

North America: There is a continuum between nickname and name: most of the American tribes had, for a long time, no other names than the nicknames given them by stronger tribes. Almost everybody knows that the Inuit refused the name Eskimo, given them by the Athabaskans. But many more tribes and peoples across North America had such nicknames. In Mexico, Chontal means 'foreigner' and Popoluca 'gibberish' in Nahuatl.

\footnotetext{
${ }^{2}$ We omitted the translation, whenever the dialectal meaning was not immediately clear.
} 
Siberia: When they conquered Siberia, Russians called the local peoples with the nicknames used by the next neighbours. Later, these peoples emancipated politically and eliminated these exonyms.

\begin{tabular}{|c|c|}
\hline old name & new name \\
\hline Cheremish & Mari \\
\hline Udmurt & Votyak \\
\hline Komi & Zyrian \\
\hline Khanti & Ostyak \\
\hline Mansi & Vogul \\
\hline Odul & Yukaghir \\
\hline Nivkh & Gilyak \\
\hline Saami & Nenets \\
\hline Lapp & Yurak \\
\hline
\end{tabular}

Table 2: Names of some indigenous peoples in Siberia

While organizing and fighting for political collective rights, the autochthonous communities did not insist on keeping their traditional First Nation names, at least in their relations with the state. The difficulties of writing phonetically the names, the necessity to have a permanent name in the bureaucratic relations with the WASP state, the instability of the Indian name (changed many times in a lifetime) and, at least in South America, the taboo on the real name (often replaced by a nickname or an appellative like cousin, brother, nephew, grandson) - all this has led to a replacement of indigenous names by Western names.

\subsection{Why do geographical nicknames appear at all? A tentative sociological explana- tion}

In Switzerland, the harmony between French-, Italian- and German-speaking Swiss, the peace between Catholics and Protestants is neither spontaneous nor easy to maintain. How does one keep Canton Ticino Italian? How does one keep a French-speaking majority in the French cantons? Switzerland was a poor country for centuries. It has only forests, who grow slowly, and grass - prone to overgrazing. Communal rules assured that nobody had too many cows, nobody cut too many trees; when somebody moved from a village to another, he did (and still does) not obtain the citizenship of his new place of residence automatically. ${ }^{3}$

In Engiadina, the poorest region, with the lowest population density, and the region most threatened by the German-speaking hegemony, these rules were the most clear-cut: not even a majority of patricians could vote to give somebody the right of citizenship.

The same rules maintained a low density of population, needed for a sustainable development in the harsh mountain climate with very low resources (before banks and ski resorts and hotels in the Alps) and the equilibrium between languages and religions.

\footnotetext{
${ }^{3}$ Netting (1973: 139; cited in Ostrom 2015: 62): "The law specifically forbade a foreigner (Fremde) who bought or otherwise occupied land in Törbel from acquiring any right in the communal alp, common lands, or grazing places, or permission to fell timber. Ownership of a piece of land did not automatically confer any communal right (genossenschaftliches Recht). The inhabitants currently possessing land and water rights reserved the power to decide whether an outsider should be admitted to community membership" and following. See as well Netting (1981: 42-69); Stevenson (1984) passim. Stevenson (2005: 85-101).
}

ISSN 1615-3014 


\section{Davart Vaschinadi.}

Anno 1670 die 8 February ais fatt Ledscha chia Ingünna Iïraschun non dess laschar ngir avaunt comün per tour aint vaschins, oder da quellas varts che chia esser pudess suot paina da milli Corunas, et qual vaschin chi fuoss tant da pauc à dar sia vusch pro quai dess esser falla traja tschient Corunas et esser ' zainza gratia priva da seis Vaschinadi; et eir schi scontrass chi fuoss la part gronda chi vulessan dar la vusch a tour aint; et chi restessan paucs oder blers chi non vulessan tour aint ne dar la vusch la pro; schi dessan quels pudair els etscher las fallas, et esser ' quels patruns et ngir ${ }^{1}$ quintats il Comün, et auters ingotta tant co schi non havessan vuschs, et ingio chia quels paucs tras furia ngissan surfatts, et chia sur loeng oder cuort pudessan ngir pro lur raschun a defensiun da ditta ledscha, schi tuott quai chia fatt fuoss esser ${ }^{1}$ per Ingotta et esser $^{1}$ annulla et chiasa et

\section{Du droit de bourgeoisie.}

Le 8 février 1670 , il fut décrété qu'aucun conseil ne doit permettre que des demandes de bourgeoisie, ou quoique ce soit de semblable, soient présentées à l'assemblée communale ${ }^{2}$, sous peine de mille couronnes d'amende, et chaque bourgeois assez vil pour donner son vote pour cela sera puni d'une amende de 300 couronnes et il sera privé sans rémission de son droit de bourgeoisie; et même s'il arrive que la majorité veuille voter pour accepter (quelqu'un comme bourgeois) et qu'il en reste un certain nombre ${ }^{3}$ qui ne veuillent pas (l') accepter, ni voter pour cela 4 , (dans ce cas) ces (derniers) pourront encaisser eux-(mêmes) les amendes, et ils seront maitres (de la situation) et considérés comme les seuls représentants du village ${ }^{5}$, et les autres (comme) rien, comme s'ils n'avaient pas le droit de vote; et s'il arrive que cette minorité doive se soumettre à

Figure 1: (Pult 1897: 212)

The council of Sent in Engiadina decrees in 1670 that no new Bürgerrecht ('franchise', droit de bourgeoisie) may be admitted. And even if some majority will vote for this, the minority is not compelled to respect the decision of the majority, and will be considered as the only masters of the village.

The contempt for the neighbours was the symbolic equivalent of these laws: it was easier to refuse somebody the Bürgerrecht if he belonged to a less-than-human village. The situation was different in Italy, the causes of campanilismo different, but the results were the same isolation and mistrust.

However, the geographical nickname creates also a relation: we have names for all villages around. They form an amorphous continuum: while the one or two village we have nicknames for are the ones familiar to us. Nicknames show which towns or village form clusters - symbolic clusters, more than economic. 


\subsection{The different levels of nicknaming}

\begin{tabular}{|c|c|c|c|c|}
\hline & level & nicknames (examples) & space & status \\
\hline 1 & $\begin{array}{l}\text { individual nick- } \\
\text { name }\end{array}$ & $\begin{array}{l}\text { (hundreds) } \\
\text { Lunga, 'the long one' (female nickname) }\end{array}$ & $\begin{array}{l}\text { in the vil- } \\
\text { lage, } \\
\text { among } \\
\text { friends }\end{array}$ & active \\
\hline 2 & $\begin{array}{l}\text { family } \\
\text { Hüsname in Al- } \\
\text { sace }\end{array}$ & $\begin{array}{l}\text { a lu'Păcăneață (onomat.) } \\
\text { a lu' Obositu 'the son of the tired one'; } \\
\text { a lu' Papă-Lapte (in Ciochina, Ialomița) } \\
\text { Cucu (in Slobozia, Cahul) }\end{array}$ & $\begin{array}{l}\text { in the vil- } \\
\text { lage }\end{array}$ & fading \\
\hline 3 & part of the village & $\begin{array}{l}\text { suseni, joseni, 'the ones living up/down' } \\
\text { căpusănii (<capul satului 'the ones from } \\
\text { the end of the village' }\end{array}$ & $\begin{array}{l}\text { in the vil- } \\
\text { lage }\end{array}$ & extinct \\
\hline $4 a$ & $\begin{array}{l}\text { attribute of the } \\
\text { village }\end{array}$ & $\begin{array}{l}\text { Stupid people from X } \\
\text { Drunkards from Y }\end{array}$ & $\begin{array}{l}\text { among } \\
\text { villages }\end{array}$ & $\begin{array}{l}\text { un- } \\
\text { known }\end{array}$ \\
\hline $4 \mathrm{~b}$ & $\begin{array}{l}\text { village nickname, } \\
\text { blason populaire, } \\
\text { Ortsneckerei } \\
\text { occit. escâi } \\
\text { 'leftwards name' }\end{array}$ & $\begin{array}{l}\text { arici 'hedgehogs'(in Cișmea) } \\
\text { broscoi 'frogs' } \\
\text { porci 'pigs' (in Mălăiești) } \\
\text { cioroi 'crows' (in Brăviceni, } \\
\text { in Cahul, Moldavia) }\end{array}$ & $\begin{array}{l}\text { cluster of } \\
\text { villages }\end{array}$ & $\begin{array}{l}\text { close to } \\
\text { extinc- } \\
\text { tion }\end{array}$ \\
\hline 5 & $\begin{array}{l}\text { regional nick- } \\
\text { name }\end{array}$ & $\begin{array}{l}\text { mocani (in Transylvania) } \\
\text { moți (in Transylvania) } \\
\text { gugulani (in Banat, Romania) } \\
\text { gavots (in France) (obscure, without et- } \\
\text { ymology) }\end{array}$ & $\begin{array}{l}\text { country } \\
\text { level }\end{array}$ & \\
\hline $5 a$ & province & $\begin{array}{l}\text { Staubirne 'Swiss Germans', } \\
\text { regățeni 'other Romanians for Transyl- } \\
\text { vanians' (in Romania) } \\
\text { sârme (Moldavians) }\end{array}$ & country & $\begin{array}{l}\text { emerg- } \\
\text { ing or } \\
\text { stable }\end{array}$ \\
\hline $5 b$ & $\begin{array}{l}\text { groups inside the } \\
\text { same people }\end{array}$ & $\begin{array}{l}\text { Litwak or Galizianer 'Jews', } \\
\text { Yekkes 'German Jews' }\end{array}$ & continent & stable \\
\hline $6 a$ & $\begin{array}{l}\text { nicknames of } \\
\text { peoples }\end{array}$ & $\begin{array}{l}\text { mucani (Romanians for Arumanians) } \\
\text { bozgori (Hungarians, for Romanians) } \\
\text { shkiptari (Albanians, for Serbians) } \\
\text { ciori 'crows' (Romanians about Gypsies) }\end{array}$ & continent & stable \\
\hline $6 b$ & distant groups & $\begin{array}{l}\text { vuzvuz (Sephardi nickname for Ashkena- } \\
\text { zis) } \\
\text { Moroko sakin 'Moroccan stabbers' } \\
\text { (Ashkenazi nickname for Moroccan } \\
\text { Jews) (Cairns 2015: 119) }\end{array}$ & $\begin{array}{l}\text { contact } \\
\text { through } \\
\text { immigra- } \\
\text { tion }\end{array}$ & obsolete \\
\hline
\end{tabular}

Table 3: The different levels of nicknaming 
We will comment on some of the above categories:

1: Individual nicknames: A less visible taboo is the one concerning the reciprocal nicknames of the spouses. Only they can use it, but nobody else.

4b): During the XVIII-th century, the nicknames are still perceived as evil. Claude-Francois Achard, in his Dictionnaire de la Provence et du Comté-Venaissin, says: "these proverbs are aspersions and slander. The same reason left out from our dictionary the nicknames given to inhabitants of certain villages of Provence, because they are the result of hatred or the envy of jealous neighbours" (cf. Achard 1785: IV; transl. D. U.).

Later, during the XIX ${ }^{\text {th }}$ century, the narrow provincial mind-set disappears after the French Revolution, and it was allowed to speak about it. Pierre A. Boissier de Sauvages, in his Dictionnaire languedocien-français, says that ,the names called nicknames, given in olden days by the inhabitants of villages to one another, are nowadays not offensive, simple jokes. But they were the results of the conflicts engendered by the wars of the feodal times" (Sauvages 1820: 280; transl. D. U.). Casimir Francois Henri Barjavel publishes in 1853 Dictons et sobriquets patois des villes, bourgs et villages du département de Vaucluse traduits, éclaircis et annotés précédés de recherches sur les proverbes injurieux ou railleurs, et suivis d'autres données paroemiologiques, which proves that the taboo had disappeared by then (cf. Barjavel 1853).

5a): Terroni, teruni. Northern Italians calls the Southern Italians with this cruel nicknames. The Jews who leave Israel are called yordim 'the ones who go down', 'leavers'. They are taboo.

5b): Galizianer machen Geld/Und Litvaker Kinder the stereotype. Yekkes 'German and Swiss Jews' are cold, punctual, exact people, hated by the other Jews.

The opposite of the nickname is the antonomasia. It is typical for Ancient Greece:

- Poeno perfidior, Scytha asperior, Scythotauris inhospitalior,

- Cretensi mendacior, Parthis vanior, Thracibus bibacior, Thessalo perfidior, Care vilior,

- Sybarita fastuosior, Milesiis effoeminatior, Arabis ditior, Pygmaeo breuior, Arcade,

- Pros Kara karizeis 'behave like a Karian among Karians, 'be rustic with the rustics'.

- $\Theta \varepsilon \sigma \sigma \alpha \lambda \iota x \eta \dot{\gamma} \gamma v v \eta$, 'a Thessalian woman', 'a poisoner',

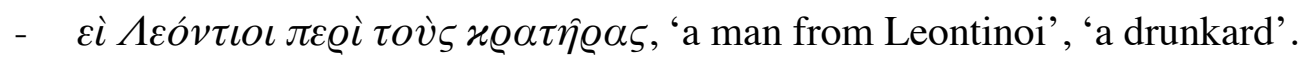

\section{Geographical nicknames in Romania}

\subsection{Oldest situation: village nicknames}

The village nicknames have different levels of transparency: we will use examples from Transylvania (cf. Ştef 2015; NARL Maramureș 1969)

a) litteral meaning:

- Breb - gușați, 'the ones with goiter' (many such villages);

- Flămânzi - nickname that became a name, nine villages 'the hungry ones';

- Săpânța - bătăuși, 'brawlers'; 
- Strâmtura, Posta, Inău - tâlhari, 'robbers';

- Borşa - olari, 'potters'.

No explanation is needed. One may assume in the first case that the inhabitants had the goiter, and in the second, that they would go often hungry. In the case of Inău etc., ethnographical studies confirm that some small distant villages lived by robbing travellers or were thieves' hideouts.

b) attribute or insult:

- Berbești - oi cornute, 'horned sheep';

- Cornești - gadine rele, 'wild beasts'

One may assume that the first ones resemble sheep, and the second ones behave like beasts.

c) not directly explainable:

- Ieud - buhaiu-n turnul bisericii, 'the ones who lifted the ox in the bell-tower';

- Dragomirești, Cornești - luna-n tău, 'the moon in the lake';

- Mara - mâți, 'cats';

- Moises - oveșeri, 'oats eaters';

- Rona de Jos - bote pălite, 'burned boots'.

They are not directly transparent for the outsiders. In the first case, it alludes to a story about stupid people who lifted an ox in the bell-tower (presumably to eat some hay that was there). The second alludes to another story about stupid people - one of them has seen the moon in the lake and called everybody with spades to take it out and put it back in the sky. For mâți, 'kittens', one has to know that the inhabitants have very light blue eyes, like the newborn cats. Oveșeri is a dialectal word; bote pălite, 'burned boots', alludes to the fact that the inhabitants are charcoal makers, and, therefore, walk all day long over embers (NALR Maramureş 1969, s. v. Rona de Jos). Numerous animal names are used as nicknames. For Transylvania, we have swine, old pigs, sheep, goats, rabbits, cats, mice, wolves, donkeys and horses; roosters, hoopoes, cuckoos, geese, ducks, magpies, owls, sparrows, crows and cranes; bed-bugs, wasps, fleas, mosquitoes, grasshoppers, crayfish - almost all animals (except the dog).

The staple food or some widespread vegetable may become a nickname as well: smeurari, afinari, oveșeri, vărzari - 'eaters of rasp- and blue-berries, oats, cabbage'; hribe, prunari, piciocari - 'eaters of mushrooms, plums and potatoes'; porodicari, morcovi, păstăi - 'eaters of tomatoes, carrots and beans.' 


\subsection{Regional nicknames}

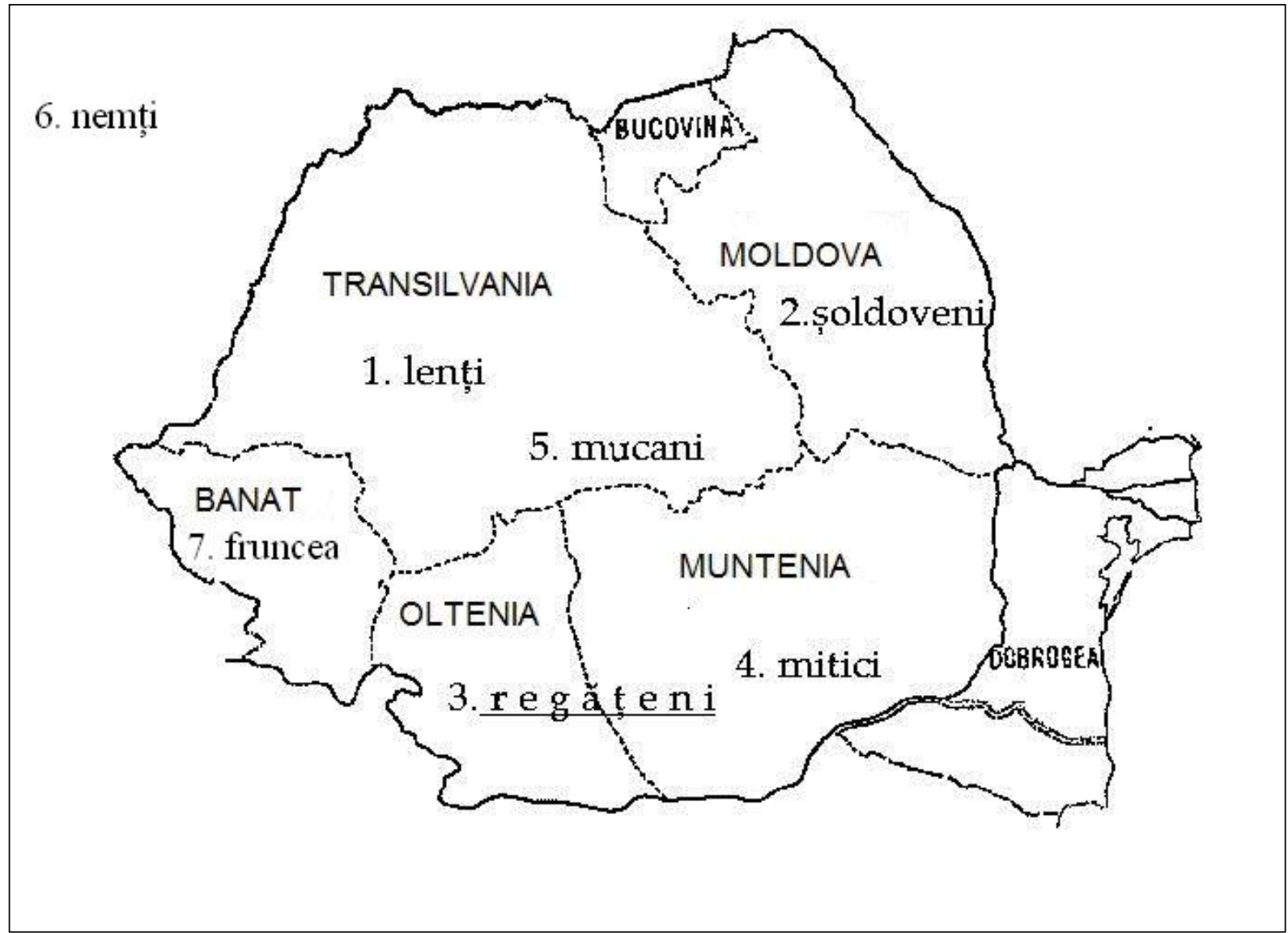

Figure 2: Geographical nicknames in Romania

In Romania, for instance,

1. There is a stereotype about the people from Transylvania - they are slow, physically and intellectually as well.

2. There are very mild stereotypes about Moldavians. The nickname şoldovean, pl. șoldoveni (mildly dismissive), used by Transylvanians and Banat people about Moldavians (cf. Ciorănescu 2001, s. v. moldovean), has a depreciative phonetical distortion: it exists in most of the languages of the Balkan Sprachbund, from which it seeped into Yiddish. (Ex. Yiddish fancyshmancy - the Yiddish case is better known and well documented in the Anglo-Saxon countries, while the Balkan Sprachbund phenomenon that triggered it is almost unknown).

Or - de unde se-atârnă harta-n cui, 'He is from the part where the map hangs on the wall' i. e. he is from the North - as the North is the upper part of the map, the one hanging (oral communication; or Cum se vede țara din Horodiștea, unde se atârnă harta în cui? [Evenimentul Zilei, 1 ian. 2014]). This third epithet is mildly derogatory and alludes to the great Moldavian emigration to Banat and Transylvania during the years 1947-1949, emigration triggered by the famine and drought.

3. regățeni, 'the ones from the Regat' (the former kingdom of Romania, before 1918). Used by the Transylvanians about people from Muntenia and Oltenia. Very mildly derisive and has mostly a connotation of 'outsiders' (cf. Scriban: 1939, s. v. regățeni), Further, there is a stere- 
otype associated to people from Oltenia - they are considered as leek eaters. Allusions to leeks in front of them are considered as offensive.

4. mitici: from Mitică, diminutive of Dumitru, frequent in Wallachia and unknown and unused in Transylvania and Banat (who use Mitru). Used by Transylvanians and people from Banat about people from Muntenia, especially Bucharest. It means 'shallow, opportunist people, who change easily friendships, political opinions, get easily bored with a task' - unreliable people, for short. (Un Mitică first reference in Caiete de dor 2/5-6: 34, 36; miticesc, ibd.: 34). Typical for the mitici is what Romanians call traseism politic - political tourism - 'a politician will move from one party to another, unbothered by ideological commitments'; miticește - adverb 'with the shallowness of a Bucharest inhabitant' (cf. Munteanu 1980: 531).

5. mocani: possibly from moacă, a shepherd's club. In Romania, collective name of the mainly pastoral inhabitants of the Sibiu county. For the Arumanians, mucani is the name of Romanians generally, mildly dismissive (Arumanians are endogamous, rich, politically conservative and xenophobic). The mocani shepherds moved their herds to remote pastures, where they met the Arumanians. The meaning widened through metonymy later (common knowledge).

6. nemți ('Germans', not on the map). Romanians associate the Germans with quality work făcut nemțește, 'made the German way - technically perfect' or impărțim nemțește 'we go Dutch' - as Romanians who drink together expect one to pay for all, or one pays for all in turns - to pay for oneself symbolizes selfishness. Nemți is the antonym of mitici (absent in most dictionaries with this meaning; common knowledge).

7. Banat - fruncea (the forehead, in dialect, the first or the best) self-designation (first attested in a poem by Gheorghe Gârda (1921).

\subsection{Spelling}

Personal and family nicknames, in Romanian, are written in upper-case letters. They are written with capitals as personal names are. Collective nicknames, regional or wider, are written in lower case, like the national names etc.

\section{Conclusions}

The old, provincial identities have been whipped out. Urbanization and education mixed and brought into contact people from different geographic origins and backgrounds. The old identities, signalized by the geographical nicknames, have been erased. Nobody knows any longer that the people from a given village were called crows or swine.

However, new regional nicknames appear, covering larger areas, like sârmă for Moldavians (cf. Pădurariu 2013). People from other regions will rarely disclose, in Banat, their birthplace. They will do that only to the closest friends and in extreme circumstances; in general, in Banat, it is considered improper to ask for the birthplace of somebody.

This proves that regional identities still exist, that regional rivalries still exist, as well as regional prides and contempt. New geographic nicknames appear (regăţeni in the 1920, sârme after 1950), which illustrates the vitality of the regional identities. 


\section{References}

Achard, Claude-François (1785): Dictionnaire de la Provence et du Comté-Venaissin. Marseille: Jean Mossy.

Augusteijn, Joost/Storm, Eric (eds.) (2012): Region and State in Nineteenth-Century Europe: Nation-Building, Regional Identities and Separatism. Basingstoke: Palgrave Macmillan.

Banfield, Edward C. (1958): The Moral Basis of a Backward Society. Glencoe: Free Press.

Barjavel, Casimir François Henri (1853): Dictons et sobriquets patois des villes, bourgs et villages du département de Vaucluse traduits, éclaircis et annotés précédés de recherches sur les proverbes injurieux ou railleurs, et suivis d'autres données paroemiologiques. Carpentras: Devillario.

Batines, Colomb de (1840): Poésies en patois du Dauphiné. Grenoble: Prudhomme.

Bell, Rudolph M. (2009): Fate, Honor, Family and Village: Demographic and Cultural Change in Rural Italy Since 1800. Chicago: Chicago University Press.

Cairns, Lucille (2015): Francophone Jewish Writers. Imagining Israel. Liverpool: Liverpool University Press.

Campbell, John R./Rew, Alan (1999): Identity and Affect: Experiences of Identity in a Globalising World. London: Pluto.

Cavanaugh, Jillian R. (2012): Living Memory: The Social Aesthetics of Language in a Northern Italian Town. London: Wiley \& Sons.

Ciorănescu, Alexandru (2001): Dicţionarul etimologic român. Bucureşti: Saeculum.

Cosco, Joseph P. (2012): Imagining Italians: The Clash of Romance and Race in American Perceptions, 1880-1910. Albany: Suny Press.

Fondazione UniversiCà (s. a.): Nomignoli dei paesi della Val Vigezzo. www.universica.it/ nomignoli-dei-paesi-della-val-vigezzo/ [12.02.2017].

Gârda, Gheorghe (1908/1921): Bănatu-i fruncea. 2. ediție. Bucuresti: Cartea Românească.

MBNews (2015): «In dialetto ti chiamano? Tutti i nomignoli della Grande Brianza». MBNews. Www.mbnews.it/2015/10/in-dialetto-ti-chiamano-gli-appellativi-della-grandebrianza/ [08.02.2017].

McCorkle Netting, Robert (1981): Balancing on an Alp: Ecological Change and Continuity in a Swiss Mountain Community. Cambridge: Cambridge University Press.

Molino, Gianni (2012): Vocabolario del dialetto valsesiano dell'Alta Valgrande. www.gian nimolino.it/documenti/101.pdf [08.02.2017].

Morley, David (2002): Home Territories: Media, Mobility and Identity. London: Routledge.

Munteanu, George: (1980): Istoria literaturii române: epoca marilor clasici. București: Editura Didactică şi Pedagogică.

Neiescu, Petru/Rusu, Grigore/Stan, Ionel (eds.) (1969): Noul atlas lingvistic pe regiuni, Maramureş (NARL Maramureș). Vol. 1. Bucureşti: Editura Academiei Republicii Socialiste România.

Nevins, Andrew/Vaux, Bert (2003): "Metalinguistic, Shmetalinguistic: The Phonology of Shmreduplication". Proceedings of the CLS 39/1: 702-721.

Ostrom, Elinor (2015): Governing the Commons. Cambridge: Cambridge University Press.

Parenti, Michael (2005): The Culture Struggle. New York: Seven Stories Press. 
Pădurariu, Cezar (2013): „Cum sunt văzuţi moldovenii de ceilalţi români”. Adevărul. http://adevarul.ro/locale/iasi/cum-vazuti-moldovenii-ceilalti-romani-valabil-mai-stereotipul -sarmaaa-1_51120af24b62ed5875dea5e7/index.html [13.10.2017].

Pult, Gaspard (1897): Le parler de Sent (Basse-Engadine). Lausanne: F. Payot.

Romansh - Rumantsch (2013): www.youtube.com/watch?v=ISW16QM41Lg [20.02.2017].

Sauvages, Pierre A. Boissier de (1820): Dictionnaire languedocien-français: suivi d'une collection de proverbes languedociens et provencaux. Alais: Martin.

Scriban, August (1939): Dicționaru limbiŭ româneștŭ. (Etimologii, înțelesuri, exemple, citațiuni, arhaizme, neologizme, provincialisme). Iaşi: Editura Presa Bună.

Sorescu, Marin (2010): La lilieci (I-III). București: Editura Art.

Stevenson, Glenn George (1984): The Swiss Grazing Commons: A Case Study in Common Property Resource Economics. Vol. 1. Madison: University of Wisconsin-Madison.

Stevenson, Glenn G. (2005): Common Property Economics: A General Theory and Land Use Applications. Cambridge: Cambridge University Press.

Ştef, Dorin (2015): „Porecle comunitare din Maramureş, în funcţie de localitate“. infoMM. https://www.infomm.ro/special-infomm-ro-porecle-comunitare-din-maramures-in-functiede-localitate/ [08.02.2017].

Tak, Herman (2000): South Italian Festivals. A Local Study of Ritual and Change. Amsterdam: Amsterdam University Press. 